\title{
VALE BOI (ALGARVE, PORTUGAL) AND THE SOLUTREAN IN SOUTHWESTERN IBERIA
}

\section{Vale Boi (Algarve, Portugal) y el Solutrense en el suroeste de la Península Ibérica}

\author{
João Cascalheira ${ }^{1}$, Nuno Bicho ${ }^{1}$, João Marreiros ${ }^{1}$, Telmo Pereira ${ }^{1}$, Marina Évora ${ }^{1}$, \\ Miguel Cortés ${ }^{2}$, Juan Gibaja ${ }^{3}$, Tiina Manne ${ }^{4}$, Frederico Regala ${ }^{1}$, Célia Gonçalves ${ }^{1}$ \\ y Patrícia Monteiro ${ }^{1}$
}

Recibido el 11 de marzo de 2013. Aceptado el 17 de junio de 2013

\begin{abstract}
Located at the crossroads of two rather different ecological and cultural worlds (Mediterranean Spain and Portuguese Atlantic), the site of Vale Boi (Algarve, Portugal) is a crucial element in understanding the economic and social traits of the communities that inhabited Southwestern Iberia during the Last Glacial Maximum (LGM). Combining an open-air with a rockshelter component, Vale Boi presents a lengthy Solutrean record starting with a Proto-Solutrean phase followed by a set of occupations in the 25 to $20.3 \mathrm{ka} \mathrm{cal}$ BP time-span. The very rich and well preserved assemblages proved that the site was treated, throughout, as a seasonal residential camp and although a striking combination of exogenous cultural traits has been identified, regional adaptive idiosyncrasies are quite evident. This paper focuses on the results of the lithics, fauna, beads and portable art analysis from Vale Boi, and their impact on the comprehension of the LGM ecodynamics in Southwestern Iberia.
\end{abstract}

Keywords: Vale Boi, Solutrean, Portugal, Last Glacial Maximum.

Resumen. Localizado en el marco de dos contextos diferentes desde el punto de vista ecológico y cultural (el Mediterráneo español y el Atlántico portugués), el yacimiento de Vale Boi (Algarve, Portugal) es un lugar fundamental para comprender la organización económica y social de las comunidades que habitaron el sudoeste de la Península lbérica durante el Último Máximo Glacial (LGM). Situado en una zona en la que se combinan ocupaciones al aire libre y en abrigo, Vale Boi presenta un amplio registro solutrense que comienza con el Proto-Solutrense y a la que le siguen un amplio número de ocupaciones entre el 25 y el 20,3 ka BP. El importante y bien preservado conjunto demuestra que este asentamiento funcionó como un campamento residencia estacional. Aunque han sido identificados diversos caracteres culturales de origen exógeno, son también evidentes los elementos adaptativos idiosincráticos. El presente artículo se centra en los resultados de los análisis del utillaje lítico, la fauna, las cuentas ornamentals y los objetos de arte mueble de Vale Boi y su impacto en la comprensión ecodinámica del LGM en el sudoeste de la Península lbérica.

Palabras clave: Vale Boi, Solutrense, Portugal, Último Máximo Glacial.

(') Núcleo de Arqueologia e Paleoecologia. FCHS. Universidade do Algarve. Campus Gambelas. P-8005 Faro (Portugal).jmcascalheira@ualg.pt

(2) Facultad de Geografía e Historia. Universidad de Sevilla. Sevilla (España).

(3) Institución Milà i Fontanals. CSIC. Barcelona (España).

(4) School of Social Science. The University of Queensland. Brisbane St Lucia, QLD 4072 (Australia) 


\section{INTRODUCTION}

Geographically limited to the westernmost regions of Europe and with a relatively short chronological range when compared to other pan-european technocomplexes, the Solutrean has been traditionally regarded as one of the first examples of human refugia during the Late Pleistocene (Jochim 1987; Straus 1991; Straus and Clark 1986). Clusters of sites in particular regions of SW Europe seem to reveal that, similarly to what has been recently argued for animal and vegetal species (Carrión et al. 2008; Gomez and Lunt 2007), Solutrean settlement patterns form a scenario of isolated refugia, that may have contracted and expanded their cultural influence as climate fluctuated (Banks et al. 2009; Cascalheira and Bicho in press; Zilhão 2013).

Solutrean settlement in lberia is, indeed, marked by very clear concentrations of sites, most of them located within ca. $50 \mathrm{~km}$ of the present coast line, in areas which were, presumably, repeatedly preferred for settlement due to the existence of diverse and reliable resources (Straus, et al. 2000). Although differences have been long-recognized between these regions, particularly in the later phases of the technocomplex in Iberia, through the preferential distribution of specific types of lithic weaponry (Jordá Cerdá 1955; Smith 1966; Straus 1977, 1990; Tiffagom 2006; Zilhão 1997), divergences have rarely been evaluated based on the detailed adaptive patterns of human populations to the characteristics of each region.

Among these clusters there are frequently geographical hiatus where the complete absence or the presence of very few sites do testify human passage but not necessarily intensive occupation (Aura et al. 2009b). During the last two decades those blank areas have progressively being punctuated with new sites, whose evidence have contributed to a better understanding of Solutrean settlement and cultural dynamics, clearly emphasizing the importance of peripheral regions.

The southwesternmost region of Iberia (Algarve, southern Portugal) was, until very recently, one of these geographical gaps, for which no evidence of Solutrean occupation were known. Actually, by the mid 1990s available data on the Upper Paleolithic occupation of Algarve were very scarce. Most of the information came from the survey projects carried out in the remote 1940s (Breuil et al. 1943; Viana 1947), the elaboration of broad regional archaeological maps (Marques, 1992, 1995; Gomes and Silva 1987; Gomes et al. 1995), or from mitigation projects in the context of road and public infrastructure constructions (Quelhas

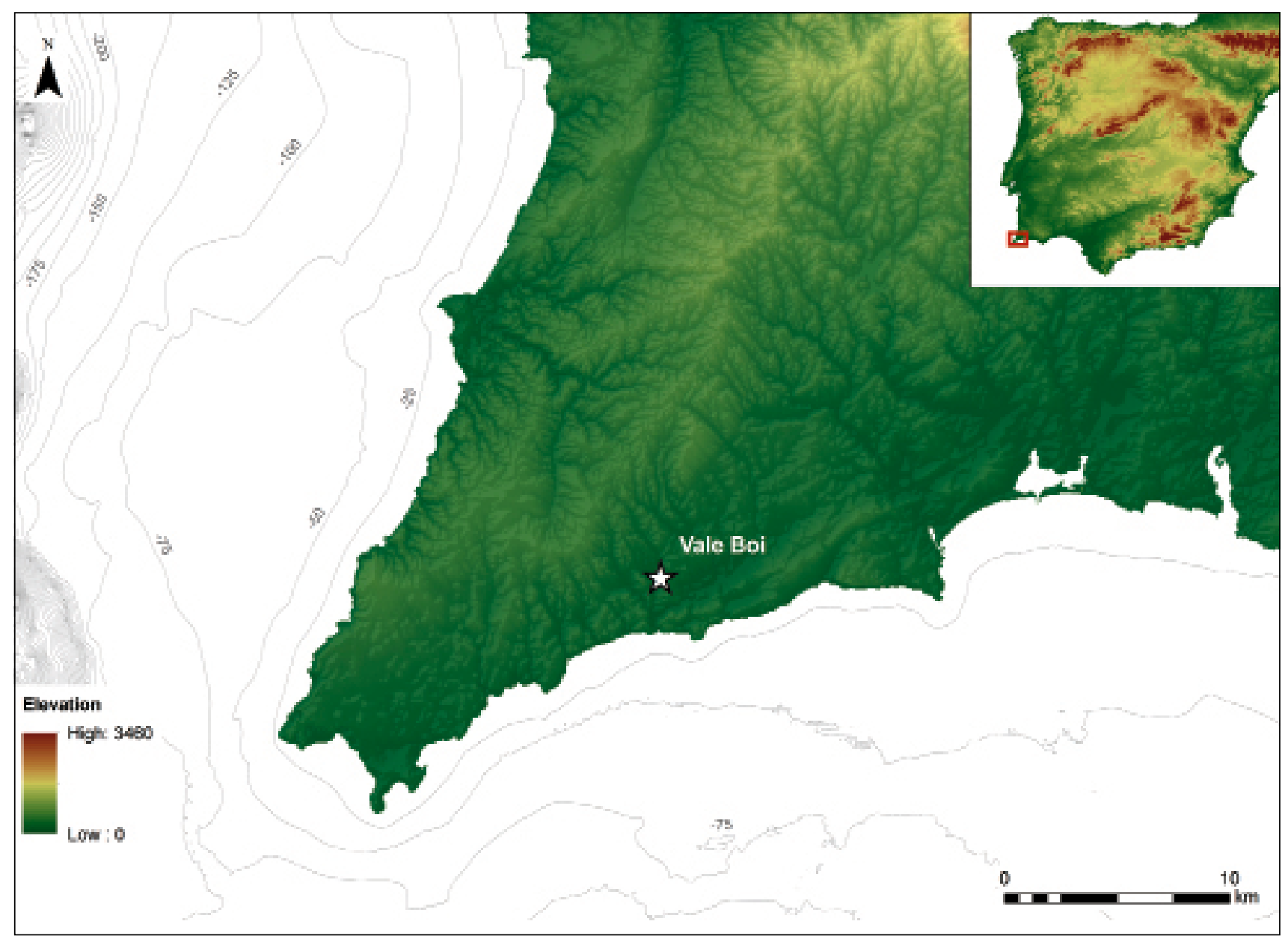

A FiguRE 1. Location of Vale Boi in southwestern Iberia. 
and Zambujo 1998). As a consequence, the region remained for several years an archaeological void between the wellknown Upper Paleolithic sites of Southern Spain and those of Central Portugal.

Only recently (1996-2001) a large, extended, survey of the Algarve for Paleolithic and Mesolithic sites was carried out as a project funded by the Portuguese National Science Foundation (FCT) (Bicho 2003). This resulted in the identification of some sixty sites with chronologies spanning from the Mousterian to the Calcolithic (Bicho 2004). Among those, six were associated to the Upper Paleolithic but only one -Vale Boi- presented a long stratigraphic sequence, with large amounts of well preserved materials, including thousands of stone tools, marine shells, terrestrial fauna, portable art, body adornments and habitat features (Bicho et al. 2007, 2012a).

Located close to the southwesternmost point of Iberia ( $37^{\circ} 05^{\prime} 4.02 " \mathrm{~N}$; 08 48' 5.41" W GDE; Fig. 1) Vale Boi has been since 2002, target of several projects that have revealed the multi-component nature of the site, as well as a fairly complete Upper Paleolithic sequence, with important levels of Magdalenian, Solutrean, Proto-Solutrean and Gravettian.

Regarding the Solutrean, Vale Boi still is, with exception of the site of Vala, whose chronological attribution to a
Solutreogravettian phase is poorly based in the presence of two small backed shouldered points and none absolute dates (Zambujo and Pires 1998), the only known site with securely dated and fairly well preserved Last Glacial Maximum (LGM) deposits in Algarve. Its location at the crossroads of two rather different ecological and cultural worlds (Mediterranean Spain and Portuguese Atlantic) makes it a crucial element in understanding the economic and social traits of the communities that inhabited Southwestern Iberia from ca. 25 to 20.3 ka cal BP.

In this paper, we present and discuss the available chronometric, technological, subsistence and symbolic data on the Solutrean occupation of Vale Boi and its impact on the traditional perspectives of LGM hunter-gatherer ecodynamics in Southern and Western Iberia.

\section{VALE BOI: AN OVERVIEW OF THE SITE, EXCAVATION AND STRATIGRAPHIC SEQUENCE}

Vale Boi is located in the eastern side of a wide valley, $2.5 \mathrm{~km}$ inland from the present-day coastline, in limestone

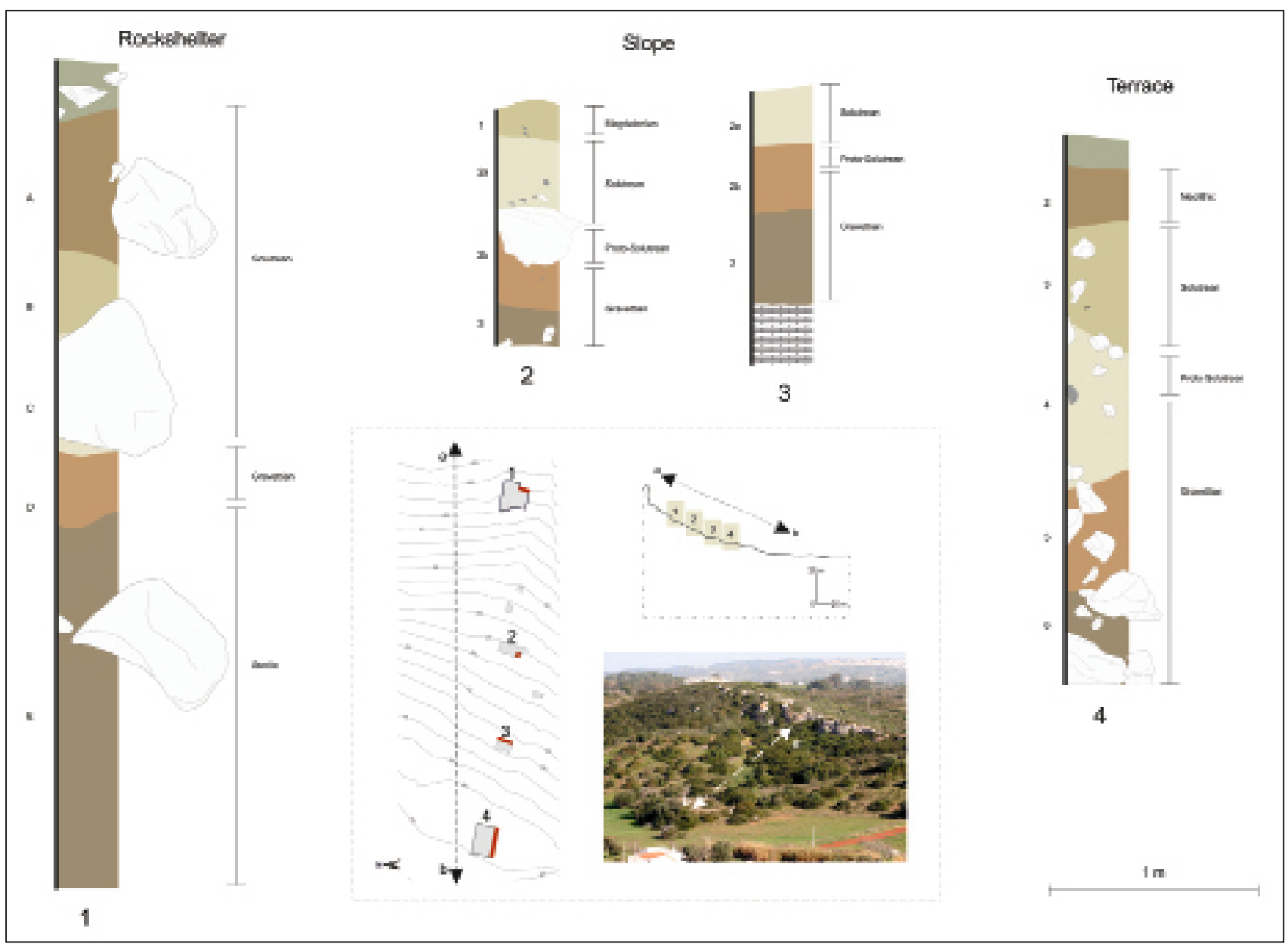

$\Delta$ FIgURE 2. Schematic stratigraphy of the different areas of Vale Boi. 
country (Bicho et al. 2007). The site occupies a wide portion of a relatively steep slope, marked by the presence of a 10-15 m high limestone cliff on the top. The slope presents a sequence of staggered platforms formed by the geological phenomena that affected the area over time.

The limits of human occupation at Vale Boi appear well marked in the eastern and western extremes of the slope: in the first case by the limestone cliff at the top, in the second, by the alluvial plain of the Vale Boi stream. The northern and southern boundaries are much less perceptible in the current landscape, but the series of test pits carried out to understand the spatial dispersion of the occupations showed a scattering of artifacts on an area that exceeds $10000 \mathrm{~m}^{2}$.

The initial test pits started in 2000 with the excavation of units G25 and Z27 located on the mid-slope section, where large concentrations of surface materials were identified, and where the topography appeared more favorable to the preservation of in situ archaeological levels (Cascalheira et al. 2008). Those test pits were progressively extended, most notably the $\mathrm{G} 25$, where the constant presence of materials throughout a stratigraphic sequence of $2.5 \mathrm{~m}$ justified the excavation of an adjacent area of $8 \mathrm{~m}^{2}$.

In 2003, another set of test pits (J20, S1 and S2) were opened, precisely in the west and east ends of the archaeological site. These pits revealed very interesting results, and once again, required, during the following years (to the present), the excavation of contiguous areas of $22 \mathrm{~m}^{2}$ in the case of the $\mathrm{J} 20$, and of $21 \mathrm{~m}^{2}$ in the S2.

Since then, archaeological work at Vale Boi have mainly focused in three distinct loci -the Rockshelter (near the cliff face), the Terrace (in the lower section above the alluvial plain) and the Slope (in between)- all with unique characteristics regarding stratigraphy, chronology and, most certainly, space functionality (Cascalheira et al. 2008). The general stratigraphic correlations of the exposed profiles of Vale Boi are shown in Figure 2.

The Slope locus covers over two thirds of the site, presenting, within the various excavated sectors, heterogeneous patterns regarding site formation processes. Some areas are, in fact, remarkably well preserved, while in others (e.g. top layers of Z27 sector) traces of washing, size sorting, and loss of faunal material were identified (Manne et al. 2012). Stratigraphically, the Slope is marked by a sequence of very fine silts, containing clasts of limestone whose size and frequency vary significantly throughout the layers. The top of the sequence comprises two highly mixed litostratigraphic units (Fig. 2) that are followed by 3 layers encompassing occupations from the Magdalenian, Solutrean, Proto-Solutrean and Gravettian. Noteworthy is the presence of a geological discontinuity between layers $2 a$ and $2 b$ that, similar to what happens in the Terrace area (see below), marks the onset of the LGM and of the Solutrean occupation in Vale Boi. No habitation features were identified in any of the Slope sectors, and based on the type and preservation conditions of artifacts and faunal remains, Bicho et al. (2010) argued that this would have been an area used mostly for garbage dumping.

The Terrace presents the longest and most complete archaeological sequence at Vale Boi. While the top litostratigraphic unit is strongly affected by agricultural work, Layer 2 contained an early Neolithic occupation with well preserved habitat features, including a hut pavement, postholes and hearths (Carvalho 2008). The sequence continues with a partially mixed layer (Layer 3 ) with the majority of the Solutrean materials deposited, most certainly, by colluvial action, separated from the remaining sequence by a thin layer of small limestone blocks. This discontinuity tops a Proto-Solutrean occupation, as well as a series of well preserved Gravettian horizons, chronologically bracketed between ca. $32 \mathrm{ka}$ and $29 \mathrm{ka}$ cal BP (Bicho et al., submitted). Although the Gravettian sequence from the Terrace is one of the richest at all levels, the most striking feature is the presence, in Layer 5 , of a very specific type of weaponry technology - the double pointed and double backed bladelets - whose specificity and chronological exclusivity lead Marreiros et al. (in press) to the identification of a regional early Gravettian facies: the Vicentine Gravettian. A single fire structure was identified in Layer 4 indicating that, together with the wide variety of lithics, fauna, body adornments and portable art, the Terrace was, most probably, an area with residential function (Bicho et al. 2010).

The same type of space functionality has also been addressed to the third and final locus: the Rockshelter. Stratigraphically, 4 major litostratigraphic units with archaeological remains were identified, containing two partially eroded horizons of Magdalenian (Layer Z) and Gravettian (Layer D) age, and a remarkably well preserved series of Solutrean occupations (Layers $A, B$ and $C$ ) whose preliminary spatial analysis revealed at least three separable archaeological horizons. At the bottom of the sequence, Layer $E$ is sterile in archaeological materials and composed of very fine sediment coming from bedrock disintegration. This area corresponds to a collapsed rockshelter. The collapse must have taken place right after the LGM as it is attested by the large collapsed-roof limestone boulders that overlay the Solutrean sequence. Throughout the stratigraphy faunal remains are exceptionally well preserved. Solutrean layers are the richest, providing a huge diversity of lithic materials, bone industry and portable art (see below). As for the Gravettian occupation, the most relevant fact is the presence of a small set of bladelet projectiles, identical to the ones recovered in Layer 5 of the Terrace locus. The radiocarbon dates obtained from each of these two layers clearly attest that those projectiles integrate the earliest dated Gravettian occupations in lberia (Marreiros et al. in press).

Very recently, a new area of $8 \mathrm{~m}^{2}$ was opened some 10 meters away from the original Rockshelter excavation, whose 
sequence is, so far, similar in the top ca. 2 meters. A considerable amount of Solutrean materials were already recovered from this new sector, with particular emphasis to a set of bifacial stemmed and winged parpallo-type points and a couple of small schist plaquettes with evidences of engraving.

\section{SOLUTREAN SEQUENCE AND CHRONOLOGY}

Presently, there are a total of 15 AMS radiocarbon dates for the Proto-Solutrean and Solutrean occupations at Vale Boi (Table 1). Twelve of these dates were obtained from unidentified charcoal samples and only three were measured from either shell or animal bones. Some of these results are, however, problematic. In the specific case of the samples coming from Terrace's Layer 3 (Wk-13685, Wk-24761, AA63305, AA-63310), a consistent age-pattern is revealed, with all radiocarbon results being close to $10.9 \mathrm{ka}$ cal BP. Although these ages were extracted from non-identified charcoal remains, two additional samples of identified species were already sent to the radiocarbon laboratory, whose results will hopefully shed some light on this apparent problem. Yet, the classification of both charcoals as Olea sp. may be, by itself and with the right caution, somehow instructive in understanding the problems with the previous samples.

Indeed, recent work by Carrión et al. (2010) have demonstrated that, when present and directly dated in Upper Paleolithic layers from Iberia sites (e.g. Buraca Grande, Cova de les Cendres), Olea sp. samples exclusively yielded Holocene ages. The explanation for their presence in Late Pleniglacial contexts has, thus, been always attributed to the existence of post-depositional processes responsible for sample percolation from Holocene deposits. Since the Solutrean sequence of the Terrace area is in direct contact with an early Neolithic occupation from where some remains of Olea sp. were recovered (Figueiral and Carvalho 2006) this seemed, at a first glance, a parsimonious hypothesis. The problem is that, even if we accept some kind of deposit perturbation, the ca. $10.8 \mathrm{ka}$ cal BP dates are incompatible with the ages obtained for the Neolithic horizon, all of ca. $7.0 \mathrm{ka}$ cal BP (Carvalho 2008). Moreover, the total absence of other Neolithic markers (e.g. ceramics) within the Solutrean levels makes it very difficult to believe in the existence of severe mixing processes between the two litostratigraphic units. On the other hand, in the chronological context of the first Holocene human occupations in Western Iberia, the AMS results from Terrace's Layer 3 are in full agreement with others coming from Epipaleolithic sites of Central Portugal (Bicho, 1994). Hopefully, the still ongoing analysis of the lithic materials would shed some light on the possibility of an, so far undetected, Epipaleolithic occupation at Vale Boi.

With respect to the other areas of the site, the reasons behind the problems in the chronology of the dated samples associated with Solutrean materials seem to be of another nature. While in the case of the Slope the two problematic samples (AA-63307 and AA-63308) fit perfectly well in the chronology of the Magdalenian occupation of Vale Boi, evidencing, as discussed above, the problems of the top layers of the Slope section; in the case of the Rockshelter (Wk-17840), some kind of charcoal contamination is the most plausible reason behind the apparent chronological inversion.

Overall, the calibration of the accepted dates clearly shows that the Solutrean occupation at Vale Boi is bracketed between ca. $25.0 \mathrm{ka}$ cal BP and $20.3 \mathrm{ka}$ cal BP (1 sigma range). Identification of specific occupational phases within this time span is possible by the existence of four different clusters of dates (Fig. 3), centered around 24.5 ka cal BP; 23.3 ka cal BP; 22 ka cal BP; and 21 ka cal BP. A fifth and

\begin{tabular}{|l|l|l|l|l|l|l|}
\hline \multicolumn{1}{|c|}{ Area } & \multicolumn{1}{|c|}{ Layer } & \multicolumn{1}{c|}{ Lab } & \multicolumn{1}{c|}{ Age } & \multicolumn{1}{c|}{ Material } & \multicolumn{1}{c|}{ Age cal BP (2 sigma) } & \multicolumn{1}{c|}{ Notes } \\
\hline Rockshelter & B & Wk-31088 & $20340 \pm 160$ & Charcoal & $24786-23845$ & R \\
\hline Rockshelter & B & Wk-17840 & $18859 \pm 90$ & Shell & $22338-21566$ & A \\
\hline Rockshelter & C & Wk-24765 & $19533 \pm 92$ & Charcoal & $23720-22684$ & A \\
\hline Rockshelter & C & Wk-26800 & $20620 \pm 160$ & Charcoal & $25045-24196$ & A \\
\hline Rockshelter & C & Wk-26802 & $20570 \pm 158$ & Charcoal & $25020-24119$ & A \\
\hline Slope & 2 & AA-63307 & $11840 \pm 280$ & Charcoal & $14821-13131$ & R \\
\hline Slope & 2 & AA-63308 & $15710 \pm 320$ & Charcoal & $19584-18155$ & R \\
\hline Slope & 2 & Wk-12131 & $17634 \pm 110$ & Bone & $21405-20518$ & A \\
\hline Slope & 2 & Wk-12130 & $18410 \pm 165$ & Bone & $22357-21505$ & A \\
\hline Slope & 3 & AA-63306 & $21420 \pm 170$ & Charcoal & $26106-25063$ & A \\
\hline Slope & 3 & Wk-16415 & $21830 \pm 195$ & Shell & $26164-25038$ & A \\
\hline Terrace & 3 & Wk-13685 & $8749 \pm 58$ & Charcoal & $10116-9548$ & R \\
\hline Terrace & 3 & Wk-24761 & $8886 \pm 30$ & Charcoal & $10171-9906$ & R \\
\hline Terrace & 3 & AA-63305 & $8825 \pm 57$ & Charcoal & $10160-9684$ & R \\
\hline Terrace & 3 & AA-63310 & $8696 \pm 54$ & Charcoal & $9888-9541$ & R \\
\hline
\end{tabular}

${ }^{*} \mathrm{R}$ - rejected; A - accepted

$\Delta$ TABle 1. AMS radiocarbon dates for the Proto-Solutrean and Solutrean of Vale Boi. 
oldest cluster is also represented in Figure 3, clearly identifying the Proto-Solutrean occupation of the Slope sector, dated to $c a .25 .5 \mathrm{ka}$ cal BP, but which will not be herein referred since it was already addressed elsewhere (Cascalheira and Bicho in press).

The Rockshelter presents the most complete Solutrean sequence, covering all dated moments, except for the most recent result of ca. $21 \mathrm{ka}$ cal BP. Nevertheless, given the chronological correspondence between Layer B of the Rockshelter and the bottom of Layer 2 of the Slope sector, it is highly probable that the most recent date coming from the top of Slope's layer 2 may also correlate with the industries recovered from layer A of the Rockshelter (to which no chronometric evidence is available), marking the final solutrean occupation of the Rockshelter and at Vale Boi.

When compared with the currently accepted chronological boundaries for the various Solutrean phases in southern and western Iberia, the results of Vale Boi seem to be slightly displaced. The main reason is not the ages per se, but the materials associated with them. Traditionally, the Solutrean in these regions has been divided into several phases based on the presence or absence of very specific weaponry types.
Stemmed and winged points, for example, are thought to be an Upper Solutrean marker, and are recognized in the Portuguese and Spanish records from ca. $23 \mathrm{ka}$ cal BP onwards (Tiffagom 2009; Zilhão 1994, 2013). At Vale Boi, however, this particular type of point appears in the Rockshelter from as early as $24.5 \mathrm{ka}$ cal BP and continues until the end of the Solutrean occupation. Their presence throughout the sequence is not uniform and variations in size have been recognized between the different layers (Cascalheira 2010; Gibaja and Bicho in press). While for the bottom layer (C), Parpalló points present a mean width and thickness of 25.93 $\mathrm{mm}$ and $5.33 \mathrm{~mm}$ respectively, for the top of the sequence (layer A) a considerable reduction in those dimensions (to 15.85 and $3.83 \mathrm{~mm}$ ) is rather evident. More interesting is the fact that layer $B$ exhibit average values that fit between the top and bottom moments. Being clearly a chronological shift, it is reasonable to propose that, over time, a successive refinement of this type of point was accomplished at Vale Boi. A trend that accompanies a certain reduction in size of the lithic assemblages as well as the progressive increase in the importance of mediterranean shouldered points (Cascalheira 2010; Bicho et al. 2012).

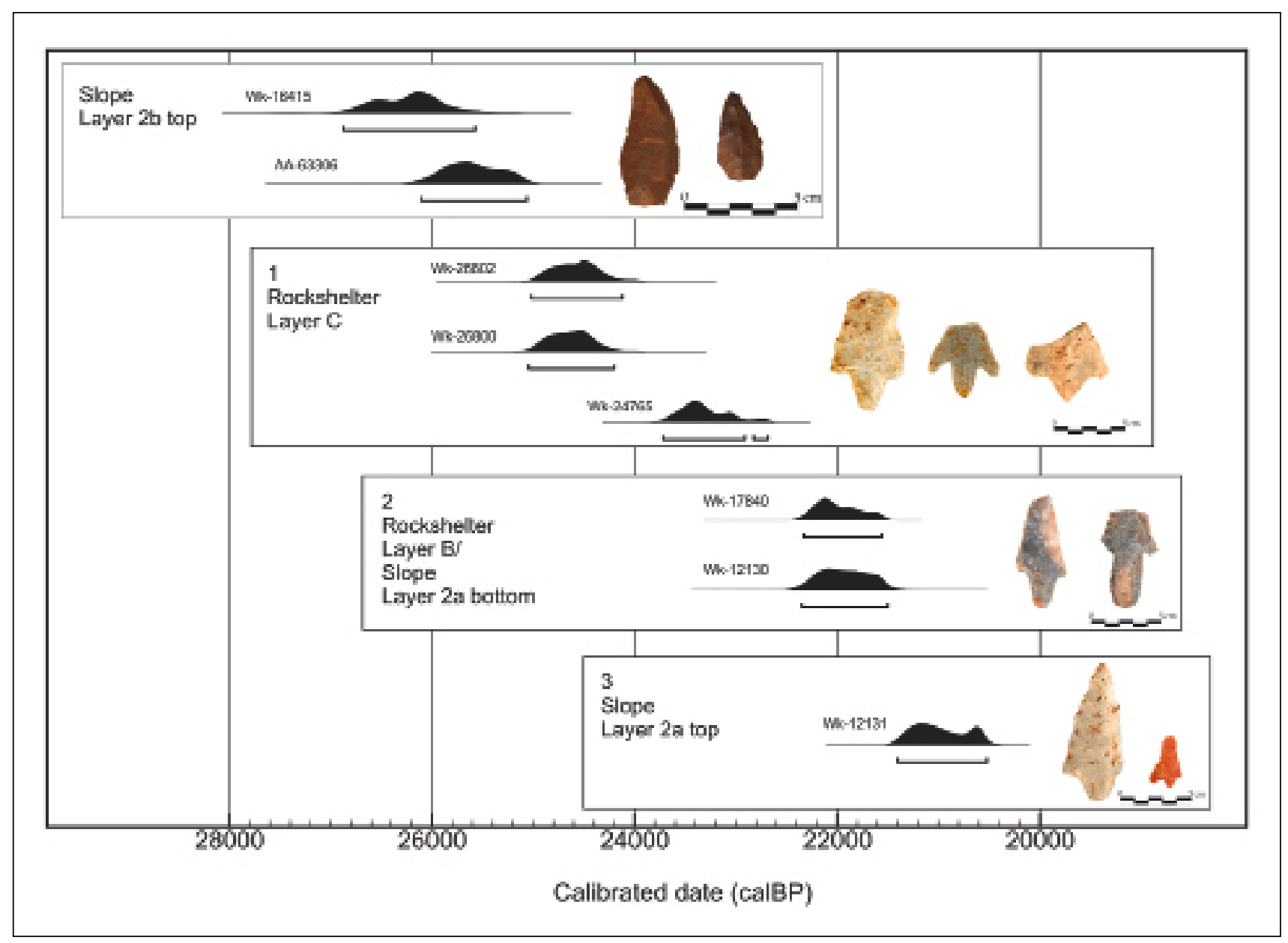

\ Figure 3. Plot of Solutrean and Proto-Solutrean accepted radiocarbon dates from Vale Boi with the three moments referred in the text. Calibration curves are IntCal09 and Marine09 (Reimer et al. 2009). 


\begin{tabular}{|l|r|r|r|r|r|r|r|r|}
\cline { 2 - 7 } \multicolumn{1}{c|}{} & \multicolumn{2}{c|}{ Layer A } & \multicolumn{2}{c|}{ Layer B } & \multicolumn{2}{c|}{ Layer C } & \multicolumn{2}{c|}{ Total } \\
\cline { 2 - 8 } \multicolumn{1}{c|}{} & \multicolumn{1}{c|}{$\%$} & $\mathrm{~N}$ & $\%$ & $\mathrm{~N}$ & $\%$ & $\mathrm{~N}$ & \multicolumn{1}{c|}{$\%$} \\
\hline End-scrapers & $12.50 \%$ & 6 & $13.77 \%$ & 19 & $15.94 \%$ & 11 & $14.12 \%$ & 36 \\
\hline Multiple tools & $0.00 \%$ & 0 & $2.17 \%$ & 3 & $1.45 \%$ & 1 & $1.57 \%$ & 4 \\
\hline Perfurators & $0.00 \%$ & 0 & $1.45 \%$ & 2 & $0.00 \%$ & 0 & $0.78 \%$ & 2 \\
\hline Burins & $0.00 \%$ & 0 & $6.52 \%$ & 9 & $2.90 \%$ & 2 & $4.31 \%$ & 11 \\
\hline Backed tools & $16.67 \%$ & 8 & $2.90 \%$ & 4 & $2.90 \%$ & 2 & $5.49 \%$ & 14 \\
\hline Truncations & $2.08 \%$ & 1 & $2.90 \%$ & 4 & $0.00 \%$ & 0 & $1.96 \%$ & 5 \\
\hline Retouched blades & $0.00 \%$ & 0 & $0.00 \%$ & 0 & $1.45 \%$ & 1 & $0.39 \%$ & 1 \\
\hline Solutrean tools & $25.00 \%$ & 12 & $16.67 \%$ & 23 & $17.39 \%$ & 12 & $18.43 \%$ & 47 \\
\hline Domestic tools & $27.08 \%$ & 13 & $31.88 \%$ & 44 & $30.43 \%$ & 21 & $30.59 \%$ & 78 \\
\hline Bladelet tools & $2.08 \%$ & 1 & $6.52 \%$ & 9 & $2.90 \%$ & 2 & $4.71 \%$ & 12 \\
\hline Others & $14.58 \%$ & 7 & $15.22 \%$ & 21 & $24.64 \%$ & 17 & $17.65 \%$ & 45 \\
\hline Totals & $100.00 \%$ & 48 & $100.00 \%$ & 138 & $100.00 \%$ & 69 & $100.00 \%$ & 255 \\
\hline
\end{tabular}

A TABLE 3. Tool groups counts for Rockshelter.

In sum, combining both chronological data with the general vertical distribution of the Solutrean tools group (see Table 3), at least three key-moments in the Solutrean sequence of Vale Boi seem to stand out (Fig. 3):

1. Between ca. 24.5 and 23.3 ka cal BP: first Solutrean occupations of the site with hunting tool-kits dominated by wide and thick stemmed and winged points and rare shouldered projectiles;

2. At ca. $22 \mathrm{ka}$ cal BP: wide variety of lithic points are present in balanced proportions, including stemmed and winged projectiles, laurel leafs and shouldered points with abrupt and plan retouch;

3. At ca. $21 \mathrm{ka}$ cal BP: final Solutrean occupation at the site with a clear predominance of small backed shouldered points and when parpalló-type points, though reduced in number, are much narrower and thinner.

\section{LITHIC INDUSTRIES}

As became clear from the description of the radiocarbon results, the Rockshelter presents the most complete Solutrean sequence of the entire site. Luckily, this is also the locus from where a complete analysis of the lithic assemblages is available. Data presented below, although only referring to the Rockshelter materials, are, therefore, likely representative of the general techno-typological patterns of the Solutrean occupation at Vale Boi. Also, previous works on this topic (Cascalheira 2008, 2010) have revealed that at the technological level, with very few exceptions, no major differences can be identified throughout the stratigraphy, and thus reduction sequences and general technological patterns can and will be presented as a whole.

More than 22.000 lithic artifacts were recovered from the Solutrean layers of the Rockshelter (Table 2). The most common raw material is chert (ca. 65\%), followed by quartz (ca. 23\%), greywacke (ca. 9\%), and only 3\% of the assemblage is composed of other rocks, like quartzite, schist or chalcedony. All these materials are available regionally, the main three from a radius of no more than $15 \mathrm{~km}$ from the archaeological site.

In the case of quartz and greywacke, the most probable source was the nearby riverbed. Both these materials were knapped through very expeditious orthogonal reduction sequences, to produce mostly flakes and rare bladelets, not often transformed into formal tools such as notches, scaled pieces and end-scrapers. Simultaneously, greywacke and quartz were also used in very specific tasks: the first, being a variety of a hard sandstone that appears at Vale Boi mostly in the form of large slabs, was frequently used as anvils with the likely task of fracturing animal bones as well as for the preparation of pigments (Bicho et al. 2012; Manne et al. 2012); quartz, on the other hand, and particularly the nodules with both less water-worning and internal homogeneity, was most likely associated with activities involving heating, such as stone-boiling for bone-grease rendering (Stiner 2003; Manne and Bicho 2009). Contrary to other areas in Vale Boi, such as the Slope from where large quantities of fire-cracked quartz were recovered, the Rockshelter presents much lower frequencies of these elements, perhaps due to differences in the functionality of spaces (Cascalheira 2010). Such apparent direct relation between raw materials and tasks are congruent with observations done among modern hunter-gatherer societies showing that raw material selection is more driven by its suitability for the intended task rather than by its flaking properties (Stout 2002; Arthur 2010). This pattern is also congruent with the pattern for almost all the Upper Paleolithic sites in Portugal (Pereira et al. 2012).

Schist was mostly used as a blank for mobile art plaquettes (see above) and chalcedony, on the other hand, 


\begin{tabular}{|c|c|c|c|c|c|c|c|c|}
\hline \multirow[b]{3}{*}{ Chips } & \multicolumn{2}{|c|}{ Layer A } & \multicolumn{2}{|c|}{ Layer B } & \multicolumn{2}{|c|}{ Layer C } & \multirow{2}{*}{\multicolumn{2}{|c|}{ Total }} \\
\hline & $\%$ & $\mathrm{~N}$ & $\%$ & $\mathrm{~N}$ & $\%$ & $\mathrm{~N}$ & & \\
\hline & $61.55 \%$ & 2356 & $60.68 \%$ & 7858 & $59.10 \%$ & 3432 & $60.42 \%$ & 13646 \\
\hline Fragments & $17.55 \%$ & 672 & $19.42 \%$ & 2515 & $17.15 \%$ & 996 & $18.52 \%$ & 4183 \\
\hline Flake & $8.39 \%$ & 321 & $8.59 \%$ & 1112 & $9.90 \%$ & 575 & $8.89 \%$ & 2008 \\
\hline Flake proximal frag. & $1.52 \%$ & 58 & $1.41 \%$ & 183 & $1.79 \%$ & 104 & $1.53 \%$ & 345 \\
\hline Flake distal frag. & $1.54 \%$ & 59 & $1.92 \%$ & 249 & $2.60 \%$ & 151 & $2.03 \%$ & 459 \\
\hline Thinning flake & $0.26 \%$ & 10 & $0.11 \%$ & 14 & $0.60 \%$ & 35 & $0.26 \%$ & 59 \\
\hline Blade & $0.50 \%$ & 19 & $0.48 \%$ & 62 & $0.52 \%$ & 30 & $0.49 \%$ & 111 \\
\hline Blade proximal frag. & $0.29 \%$ & 11 & $0.26 \%$ & 34 & $0.22 \%$ & 13 & $0.26 \%$ & 58 \\
\hline Blade distal frag. & $0.50 \%$ & 19 & $0.44 \%$ & 57 & $0.50 \%$ & 29 & $0.46 \%$ & 105 \\
\hline Bladelet & $2.06 \%$ & 79 & $1.84 \%$ & 238 & $1.96 \%$ & 114 & $1.91 \%$ & 431 \\
\hline Bladelet proximal frag. & $0.97 \%$ & 37 & $0.86 \%$ & 111 & $0.53 \%$ & 31 & $0.79 \%$ & 179 \\
\hline Bladelet distal frag. & $2.38 \%$ & 91 & $1.88 \%$ & 243 & $1.77 \%$ & 103 & $1.93 \%$ & 437 \\
\hline Burin Spall & $0.13 \%$ & 5 & $0.08 \%$ & 10 & $0.05 \%$ & 3 & $0.08 \%$ & 18 \\
\hline Core & $0.76 \%$ & 29 & $0.62 \%$ & 80 & $0.98 \%$ & 57 & $0.74 \%$ & 166 \\
\hline Core maint. products & $0.29 \%$ & 11 & $0.17 \%$ & 22 & $0.22 \%$ & 13 & $0.20 \%$ & 46 \\
\hline Anvils & $0.13 \%$ & 5 & $0.13 \%$ & 17 & $0.21 \%$ & 12 & $0.15 \%$ & 34 \\
\hline Manuports & $0.03 \%$ & 1 & $0.03 \%$ & 4 & $0.07 \%$ & 4 & $0.04 \%$ & 9 \\
\hline Tools & $1.18 \%$ & 45 & $1.09 \%$ & 141 & $1.81 \%$ & 105 & $1.29 \%$ & 291 \\
\hline Total & $100.00 \%$ & 3828 & $100.00 \%$ & 12950 & $100.00 \%$ & 5807 & $100.00 \%$ & 22585 \\
\hline
\end{tabular}

A TABLE 2. Solutrean lithic assemblage of Vale Boi - Rockshelter.

was knapped to produce few flakes but it is also present in the form of a bifacial preform.

Chert is present in a wide range of chromatic and grainsize varieties. Although the identification of each specific source is still in progress, a large number of primary positioned chert deposits have already been identified in the region (Boix et al. 2011; Verissimo 2004, 2005), whose macroscopic characteristics of the collected samples seem to match some of the types present in Vale Boi (Santos 2005). This correlation between known sources and artifacts indicate an exploitation of the westernmost cliff borders that delimitate the present dry land. Nonetheless, the existence of non-yet-identified sources seems to open the possibility of exploitation of territories located further north, in the Algarve mountainous regions and eastern adjacent areas. If confirmed by ongoing surveys and analysis, these sources might help to shade light on the relation between foodstone acquisition, namely to understand if chert was acquired within dedicated expeditions or if it was gathered when encountered during the execution of other tasks.

Both nodular and tabular volumes were used, always very small in size and with frequently natural defects. These characteristics must have greatly influenced the general technological options, namely the overall dimension of the debitage products and tools (Cascalheira 2010).

Nodules were, most certainly, introduced at the site with none or very little preparation since decortication is well attested by high frequencies of blanks and tools with total or large percentages of cortex in their dorsal surfaces (Cascalheira 2008). Chert reduction sequences were fairly simple and involve mostly unidirectional or bidirectional prismatic strategies. Core maintenance products are frequent, particularly crested pieces and trimming elements. Flakes are the most common debitage element (ca. 62\%), followed by bladelets (ca. 23\%) and blades (ca. 6\%). The former was also the favorite blank type to the manufacture of formal tools, while blades and bladelets occupy the second and third options, respectively.

Typologically, the chert assemblage is dominated by end-scrapers, notches, splintered pieces and unevenly retouched blades/flakes (Table 3). Differences between layers in the typological composition of the assemblages are, as already mentioned, mostly seen in the elements coming from the Solutrean tools group and backed shouldered points.

Finally, use-wear analysis of the lithic assemblage revealed that a wide range of activities were accomplished (Gibaja and Bicho 2006). The use of retouched and non-retouched edges for working wood, hide and other soft materials (probably meat, fresh skin, etc.) has been identified. Some of these pieces, either retouched or not, were also used in the manufacture of bone and antler tools (Évora 2007).

\section{FAUNAL RECORD}

Tables 4 and 5 present the NISP (Number of Identifiable Species) and MNI (Minimum Number of Individuals) counts/percentages for respectively vertebrates and shellfish remains recovered from the Solutrean levels of each area of Vale Boi. It should be noted that the values presented for 


\begin{tabular}{|c|c|c|c|c|c|c|}
\hline \multirow{2}{*}{ Taxon Observed } & \multicolumn{2}{|c|}{ Rockshelter } & \multicolumn{2}{|c|}{ Slope } & \multicolumn{2}{|c|}{ Terrace } \\
\hline & NISP & $\mathrm{NISP} \%$ & NISP & $\mathrm{NISP} \%$ & NISP & NISP\% \\
\hline \multicolumn{7}{|l|}{ Ungulates } \\
\hline Bos primigenius & 73 & 2.4 & 32 & 1.4 & 3 & 0.4 \\
\hline Equus caballus & 276 & 9.0 & 193 & 8.5 & 56 & 8.1 \\
\hline Equus sp. (possibly hydruntinus) & 27 & 0.9 & 48 & 2.1 & 10 & 1.5 \\
\hline Cervus elaphus & 371 & 12.1 & 813 & 35.9 & 149 & 21.6 \\
\hline Sus scrofa & & & 1 & 0.0 & 1 & 0.1 \\
\hline Capra/Ovis & 3 & 0.1 & 5 & 0.2 & 3 & 0.4 \\
\hline \multicolumn{7}{|l|}{ Small Mammals } \\
\hline Oryctolagus cuninculus & 2274 & 74.4 & 1147 & 50.7 & 457 & 66.3 \\
\hline Microtus sp. & 7 & 0.2 & & & & \\
\hline \multicolumn{7}{|l|}{ Carnivores } \\
\hline Vulpes vulpes & 4 & 0.1 & 2 & 0.1 & & \\
\hline Canis lupus & 2 & 0.1 & 1 & 0.0 & & \\
\hline Canis spp. & 3 & 0.1 & 3 & 0.1 & & \\
\hline Panthera leo & & & 1 & 0.0 & 2 & 0.3 \\
\hline Lynx pardina & 1 & & 3 & 0.1 & 1 & 0.1 \\
\hline Felis sylvestris & 6 & & 5 & 0.2 & 2 & 0.3 \\
\hline Mustela sp. & 1 & & 1 & 0.0 & & \\
\hline Martes sp. & & & 3 & 0.1 & & \\
\hline \multicolumn{7}{|l|}{ Aves } \\
\hline Small bird & & & 1 & 0.0 & 1 & 0.1 \\
\hline Medium bird & 4 & 0.1 & 1 & 0.0 & & \\
\hline Large bird & & & 1 & 0.0 & 1 & 0.1 \\
\hline Totals & 3052 & & 2261 & & 686 & \\
\hline
\end{tabular}

A TABLE 4. Solutrean vertebrate NISP and NISP\% for Vale Boi site areas (Terrace, Mid Slope and Rockshelter).

\begin{tabular}{|c|c|c|c|c|c|c|}
\hline \multirow[t]{2}{*}{ Taxon Observed } & \multicolumn{2}{|c|}{ Terrace } & \multicolumn{2}{|c|}{ Slope } & \multicolumn{2}{|c|}{ Rockshelter } \\
\hline & MNI & MNI\% & MNI & MNI\% & MNI & MNI\% \\
\hline Mytilus edulis & & & 21 & 5.1 & 5 & 3.7 \\
\hline Pecten maximus & & & 3 & 0.7 & 1 & 0.7 \\
\hline Acanthocardiasp. & & & 2 & 0.5 & 1 & 0.7 \\
\hline Cerastoderma edule & & & & & 13 & 9.6 \\
\hline Cardiidae & & & & & 2 & 1.5 \\
\hline \multicolumn{7}{|l|}{ Callista chione } \\
\hline Ruditapes decussatus & 1 & 33 & 9 & 2.2 & 2 & 1.5 \\
\hline Veneridae & & & 2 & 0.5 & & \\
\hline Patella sp. & 2 & 67 & 374 & 90.8 & 106 & 77.9 \\
\hline \multicolumn{7}{|l|}{ Cerithiidae } \\
\hline Lacuna parva & & & & & 1 & 0.7 \\
\hline Littorina & & & & & 4 & 2.9 \\
\hline \multicolumn{7}{|l|}{ Naticidae } \\
\hline Gibbula sp. & & & 1 & 0.2 & & \\
\hline Pollicipes pollicipes & & & & & 1 & 0.7 \\
\hline Totals & 3 & & 412 & & 136 & \\
\hline
\end{tabular}

- TABLE 5. MNI counts and \% MNI of shellfish (and Pollicipes pollicipes) for Terrace, Slope and Rockshelter assemblages.

the Terrace are incomplete given the ongoing state of the analysis.

Similarly to the patterns observed from the Gravettian and Magdalenian occupations (Manne and Bicho 2009;
Manne 2010; Manne et al. 2012), Solutrean vertebrate assemblage is dominated by rabbit, red deer and horse. Although in minor quantities, other species are also present, like wild ass, aurochs and ibex. Carnivores and birds were 
identified in small numbers, the former likely hunted and skinned by humans given the lack of evidence for gnawing or ravaging, the prominence of lower limb and foot bones, and the presence of some cutmarks in their skeletal remains (Manne et al. 2012). This is also the case of rabbits, whose comparison of the patterns of skeletal representation at Vale Boi with data from other Portuguese Upper Paleolithic sites (Manne and Bicho 2009), together with the absence of clear taphonomic marks of non-human predators, support the assumption that rabbit remains were largely or exclusively accumulated by humans (Manne 2010).

High values of rabbit remains at Vale Boi during the Solutrean are in agreement with data coming from other Pleniglacial sites in southern and western lberia (Aura et al. 2009). Nonetheless, one of the most interesting and quite unique facts on the solutrean rabbit assemblage of Vale Boi is the overrepresentation, when compared to the Gravettian and Magdalenian layers, of a particular skeletal element: the calcaneus. Since no taphonomic factors seem to be associated with this differential representation, either between layers or between site sectors, Manne et al. (2012) stress that the greater number of rabbit calcanei in the Solutrean levels are most probably related with particular cultural choices.

Ungulate assemblages are extensively fragmented suggesting an intensive processing of bones. Identification of specific impact damages for opening the medullar cavities of large quantities of horse and red deer remains, including the first and second phalanges of the latter and first phalanges of the former, clear indicate that Solutrean hunters at Vale Boi were targeting bone marrow and grease. Together with the large amount of fire-cracked rocks recovered throughout the site, bone fragmentation patterns suggest that several ungulate remains have undergone a process of grease-rendering (Manne and Bicho 2009). This practice of intensive resource exploitation is not exclusive to the Solutrean assemblages and has been also identified from the early Gravettian occupations. Similar rendering processes have been proposed for the Solutrean levels of Nerja, based in the degree of fragmentation in long bone epiphyses of ibex remains (Aura et al. 2009).

All body parts of ungulates are relatively well represented, indicating that most animals were brought back to the site whole and that grasslands were, most certainly, in close proximity (Manne 2010, Bicho et al. submitted). Also, age profiles for the two most abundant ungulate species (horse and red deer) have revealed that the assemblage is dominated by prime-aged adults. Fetal/neonate red deer and horse remains are well represented too, indicating that hunter's targets were, most probably, maternal herds of red deer and small herds of horse in the late spring (Manne et al. 2012).

Shellfish sample is almost completely dominated by limpets, a rocky shore species still very common in the southwestern and western coasts of Algarve. Species from sandy and muddy environments are also present at the Solutrean levels, such as cockles and carpet shells, albeit in much lower percentages. Although the types of species seem to remain the same from Gravettian to Solutrean, a considerable decrease in the total shellfish MNI can be noticed (Manne and Bicho 2011), presumably associated with the increasing distance from the site to the shoreline during the LGM (Colonese et al. 2011).

\section{ART AND ORNAMENTS}

Some species of shells, from both marine and riverine environments, were also used as body adornments at Vale Boi. A total of 36 naturally or anthropically perforated shells were recovered from the Solutrean levels that were likely used as ornaments, of which 10 are Littorina obtusata/fabalis, 6 are Trivia monacha/arctica, 6 are Theoduxus fluviatilis, and 14 are Dentalium shells (Regala 2011). Comparing with the Gravettian phase, Solutrean species are much more diverse and evenly represented. Bicho (2009) argued very recently that the clear differences of the ornamental habits and style recognized during the Gravettian between Vale Boi and the sites from Central Portugal are much more subtle during the Proto-Solutrean and the Solutrean phases. This shift is, once again, and similarly to what was verified in the lithic weaponry (Bicho et al. 2004), most certainly related with changes in the expansion of the spheres of cultural influence at the onset of the LGM (Cascalheira and Bicho in press).

The integration of Vale Boi in a wider territory of influence is also attested by the discovery of several elements of mobile art. The most representative of all is a small schist plaquette with the engraving of four animal figures (three aurochs and one possible cervid), whose complete analysis and interpretation have been recently published by Bicho et al., (2012b) and Simón et al. (2012).

The plaquette was found in rockshelter's layer $\mathrm{C}$ and thus can be associated with the first Solutrean occupations at Vale Boi (ca. 24.5-23.3 cal ka BP). In fact, this is one of the oldest securely dated art element in southern Iberia and, based on the iconographic zoomorphic elements represented, Bicho et al. (2012) attest its similarity with other representations present in the late Gravettian/Middle Solutrean in the Mediterranean art sequence, and in some of the Coa valley sites (Aubry and Sampaio 2009). However, the attribution of this specific element to what is traditionally defined as Middle Solutrean is highly problematic. Within the traditional subdivision of the Solutrean technocomplex for the Valencia region (Villaverde 1994), for example, this type of engraved slabs are not associated with any tanged or shouldered projectiles, but with assemblages dominated 
by high frequencies of points a face plan and laurel leafs. As mentioned above, none of these categories is dominant in the Solutrean horizons of the Rockshelter, not even in the earliest occupations, proving, thus, that the relation between each one of these components can be very different depending on the region.

\section{SUMMARY AND CONCLUSIONS}

Vale Boi seems to contribute specifically in three main categories of data for a better understanding of the Solutrean in Southern and Western Iberia: (1) chronology, (2) regional adaptive patterns and (3) general operating modes of cultural influence networks between different regions during the LGM.

Regarding chronology, Vale Boi provides the one of the oldest set of radiocarbon dates from an occupation with traditionally defined Upper Solutrean materials. The presence of stemmed and winged points in the 24.5-23.3 ka cal BP period, have no parallel in any other site of Iberia. Though anomalous from a traditional perspective, this fact is partially corroborated by the recent AMS dates from Cueva Ambrosio (Andalucia, Spain), that reveal much older results than previously thought for the Solutreogravettian level (Jordá Pardo et al. this volume). The reassessment of the Solutrean chronology and internal organization in southern Iberia is an urgent task but for now we strongly believe that, as already argued by Straus (1976) for the Cantabria region, the use of specific types of Solutrean projectiles for the identification of chronologically well-defined evolutionary phases within the technocomplex is a tendency that to be continued, should be with some prudence, paying particular attention to the particularities of the regional sequences.

Regional idiosyncrasies are rather evident at Vale Boi, primarily in resources management and use. Most patterns identified in the Solutrean levels, such as subsistence variability and intensification, raw materials specialized usage, reduced lithic blank dimensions due to small and low quality chert nodules, among others, were already present in the previous Gravettian occupations at the site (Manne et al. 2012, Marreiros 2009, Marreiros et al. 2012). This fact clearly indicates that some of the adaptive strategies were resilient through time and impermeable to the major shifts in the techno-typological novelties brought about with the advent of each technocomplex. Thus, the assimilation of the Solutrean "package" at Vale Boi seems to be evident only in very specific components of the archaeological record, including lithic weaponry, shell beads and portable art. All these are usually regarded as good stylistic and territorial markers and must have worked, therefore, as the main interregional aggregative elements, expressing the broad identity of the Solutrean of Mediterranean facies (Jordá Cerdá 1955; Tiffagom 2006).

Overall, southwestern Iberia seems to have worked as an area of ecological refuge during the LGM, in which the diversity and specificity of the available resources allowed communities of hunter-gatherers to maintain a regional adaptive model and, at the same time, to be a contact interface between the two closest Solutrean foci of Southern Spain and Central Portugal.

\section{ACKNOWLEDGMENTS}

We would like to thank a diversity of agencies that provided directly or indirectly means to obtain data from Vale Boi: Fundação para a Ciência e Tecnologia (Grants PTDC/ HAH/64184/2006, SFRH/BD/65527/2009 and PTDC/HISARO/117540/2010), National Geographic Society (Grant \#8045-06), National Science Foundation, and Wenner-Gren Foundation for Anthropological Research (Grant \#8290). •

\section{REFERENCES}

AubRY, T. and SAmPAIO, J. D. 2008: "Fariseu: cronologia e interpretação funcional do sítio". In A. T. Santos y J. D. Sampaio (eds.): Pré-história gestos, III congresso de arqueologia Trás-os-Montes, Alto Douro e Beira interior. ACDR de Freixo de Numão I. Oporto: 7-30.

Aura, J. E., JordÁ, J. F., Morales, J. V., Pérez, M., Villalba, M.-P. and ALCOVER, J. P. 2009a: "Economic Transitions in Finis Terra: the Western Mediterranean of Iberia, 15e7 ka BP". Before Farming 2009/2: article 4: Online version. http://www.waspress.co.uk/journals/beforefarming/.

Aura, E., JordÁ Pardo, J. and Fortea Pérez, J. 2009b: "La Cueva de Nerja (Málaga, España) y los inicios del Solutrense en Andalucia". Zhepyrvs 59: 67-88.

Banks, W.E., Zillã̃o, J., D'erRico, F., Kageyama, M., Sima, A. and RonchITELLI, A. 2009: "Investigating links between ecology and bifacial tool types in Western Europe during the Last Glacial Maximum." Journal of Archaeological Science 36: 2853-2867.
BıCHO, N. F. 1994: "The end of the Paleolithic and the Mesolithic in Portugal". Current Anthropology 35 (5): 664-674.

BICHO, N. 2003: "A importância dos recursos aquáticos na economia dos caçadores-recolectores do Paleolítico e Epipaleolítico do Algarve". Xelb 3: 11-26.

- 2004: "As comunidades humanas de caçadores-recolectores do Algarve Ocidental - perspectiva ecológica". In A.A. Ferro, M. J. Tavares e J. Cardoso (eds.) Evolução Geohistórica do Litoral Português e fenómenos correlativos. Universidade Aberta. Lisboa: 359396.

- 2009: "Fashion and glamour: weaponry and beads as territorial markers in Southern Iberia". In F. Djindjian, J.K., Kozlowski and N. Bicho (eds.): Le concept de territoires dans le Paléolithique Supérieur Européen. British Archaeological Reports. Oxford: 243-251.

Bicho, N., CAscalheira, J. and Marreiros, J. 2012a: "On the (L)edge: the case of Vale Boi rockshelter (Algarve, Southern Portugal)". In K. Bergsvik and R. Skeates (Eds.): Caves in Context. Oxbow Books. Oxford: 65-81. 
Bicho, N., Gibaja, J. F., Stiner, M. and Manne, T. 2010: "Le paléolithique supérieur au sud du Portugal: le site de Vale Boi". L'Anthropologie 114: 48-67.

BICHO, N., StINER, M. and LINDLY, J. 2004: "Shell Ornaments, bone tools and long distance connections in the Upper Paleolithic of Southern Portugal". In M. Otte (ed.): La Spiritualité. Actes du colloque international de Liège, decembre 2003. ERAUL 106. Liège: 71-80.

Bicho, N., Stiner, M., MOURA, D. and LUCEnA, A. 2007: "Rockshelter studies in South- western Iberia: the case of Vale Boi (Algarve, Southern Portugal)". In M. Kornfeld, S. Vasil'ev, L. Miotti (eds.): Proceedings of the XV World Congress UISPP (Lisbon, 4e9 September 2006) 14 On Shelter's Ledge: Histories, Theories and Methods of Rockshelter Research. British Archaeological Reports 1655. 0xford: 75-82.

BıCHO, N., Simón, M. and CORTÉS, M. 2012b: "A Solutrean engraved plaquete from the site of Vale Boi, Portugal". Quartar 59: 153-164.

Bicho, N., Manne, T., Marreiros, J., Cascalheira, J., Pereira, T., Regala, F., Évora, M., Gonçalves, C. and INFAntinI, L. (submitted): "The ecodynamics of the first modern humans in Southwestern lberia: the case of Vale Boi, Portugal". Quaternary International.

BoIX, J., ORTEGA, D., TeRRADAS, X. and BICHO, N. 2011: "Las silicificaciones en el Algarve y su aprovechamiento en la Prehistoria regional". Workshop Silex: trazadores litológicos de larga distancia durante la Prehistoria de la Península lbérica. Burgos.

Breull, H., Vaultier, M. and ZbyszeWski, G. 1943: "Première Prospection Paléolithique en Algarve". $4{ }^{\circ}$ Congresso Luso-Espanhol para o progresso das Ciências. Associação para o Progresso das Ciências. Porto: 48-62.

Carrión, J. S., Finlayson, C., Fernández, S., Finlayson, G., AlluÉ, E., LópezSáez, J. A., López-Garcia, P., Gil-Romera, G., Bailey, G. and GonzálezSAMPÉRIZ, P. 2008: "A coastal reservoir of biodiversity for Upper Pleistocene human populations: palaeoecological investigations in Gorham's Cave (Gibraltar) in the context of the Iberian Peninsula". Quaternary Science Reviews 27: 2118-2135.

Carrión, J. S., Fernández, S., González-Sampériz, P., Gil-Romera, G., BadalGarcia, E., Carrión-Marco, Y., López-Merino, L., Sáez, J. A. L., Fierro, E. and BURJACHS, F. 2010: "Expected trends and surprises in the Lateglacial and Holocene vegetation history of the Iberian Peninsula and Balearic Islands". Review of Palaeobotany and Palynology 162: 458-475.

CARVAlho, A., 2008: "A neolitização do Portugal meridional. Os exemplos do Maciço Calcário Estremenho e do Algarve ocidental". Promontoria Monográfica 12. Universidade do Algarve. Faro.

CAsCalheiRA, J. 2009: "Tecnologia lítica solutrense do abrigo de Vale Boi (Algarve, Portugal): resultados preliminares". In Orjia (coord.): Actas das I Jornadas de Jovenes en Investigacion: dialogando con la cultura material, I. Compañia Española de Reprografía y Servicios, S.A. Madrid.

- 2010: Tecnologia lítica do abrigo Solutrense de Vale Boi. Cadernos da Uniarq 5. UNIARO. Lisboa.

CASCALHEIRA, J. and BICHO, N. In press: "Hunter-gatherer ecodynamics and the impact of the Heinrich Event 2 in Central and Southern Portugal". Quaternary International (2013) http://dx.doi.org/10.1016/j. quaint.2013.05.039

CASCALHeIRA, J., MARReiros, J. and Bicho, N. 2008: "As intervenções arqueológicas de 2006-2007 no sítio paleolítico de Vale Boi". Xelb 8: 23-35.

Colonese, A., Mannino, M., Bar-Yosef, O., Mayer, D.E., FA, D., Finlayson, J., LUBELL, D. and StINER, M. 2011: "Marine mollusc exploitation in Mediterranean prehistory: an overview". Quaternary International 239: 86-103.

ÉVORA, M. 2007: Utensilagem óssea do Paleolítico Superior português. Tese de mestrado em Arqueologia. Universidade do Algarve.

Figueiral, I. and Carvalho, A. 2006: "Rocha das Gaivotas e Vale Boi: os restos vegetais carbonizados, vestígios da vegetação meso-neolítica". Promontoria 4: 81-92.
GIBAJA, J. and BıCHO, N. 2006: "La función de los instrumentos líticos en el asentamiento de Vale Boi (Algarve, Portugal). Estudio del utillaje gravetiense y solutrense". Sagvntvm 38: 9-21.

GIBAJA, J. and BICHO, N. In press: "Provenance, technologie, morphologie et I'utilisation de points Protosolutrean et Solutrean de Vale Boi (Algarve, Portugal meridional): resultants preliminaires". M. Almeida B. Walter and M. J. Neves (eds.): Le Solutréen 40 an après la publication du Smith '66. International Conference. Preuilly-sur-Claise, October 2007. Advance publication. SERAP Vallée de la Claise. Preuilly-sur-Claise.

GoMES, M. and SILVA, C. 1987: "Levantamento Arqueológico do Algarve. Concelho de Vila do Bispo". Delegação Regional do Sul, Secretaria de Estado da Cultura. Faro.

Gomes, M., CARDoso, J. And Alves F. 1995: "Levantamento Arqueológico do Algarve. Concelho de Lagoa". Câmara Municipal de Lagoa. Lagoa.

Gómez, A. and LuNT, D. 2007: "Refugia within refugia: patterns of phylogeographic concordance in the Iberian Peninsula". In S. Weiss and N. Ferrand (Eds.), Phylogeography of Southern European Refugia: Evolutionary Perspectives on the Origins and Conservation of European Biodiversity. Springer. Dordrecht: 155-188.

JocHIM, M. 1987: "Late Pleistocene refugia in Europe". In O. Soffer (ed.): The Pleistocene Old World. Regional Perspectives. Plenum. London and New York: 317-331.

JoRDÁ CERDÁ, F. 1955: El Solutrense en España y sus problemas. Diputación Provincial de Asturias. Servicio de Investigaciones Arqueológicas. Oviedo.

MANNE, T. 2010: "Upper Paleolithic foraging decisions and early economic intensification at Vale Boi, Southwestern Portugal". PhD. Dissertation. University of Arizona. Tucson.

MANNE, T. and BICHO, N. 2009: "Vale Boi: rendering new understandings of resource intensification and diversification in southwestern Iberia". Before Farming 2009/ 2: article1: Onlineversion.http://www. waspress.co.uk/journals/beforefarming/.

Manne, T., Cascalheira, J., Évora, M., Marreiros, J. and Bicho, N. 2012: "Intensive subsistence practices at Vale Boi, an Upper Paleolithic site in southwestern Portugal". Quaternary International 264: 83-99.

Marques, T. 1992: Carta arqueológica de Portugal. Portimão, Lagoa, Silves, Albufeira, Loulé, São Brás de Aportel. IPPC. Lisboa.

- 1995: Carta arqueológica de Portugal. Faro, Olhão, Tavira, Vila Real de Santo António, Alcoutim. IPPC. Lisboa.

MarReIRos, J. 2009: As primeiras comunidades do Homem moderno no Algarve Ocidental: Caracterização paleotecnológica e paleoetnográfica das comunidades gravetenses e proto-solutrenses de Vale Boi (Algarve, Portugal). Master Thesis. Universidade do Algarve. Portugal.

Marreiros, J., Bicho, N., Gibaja, J., Cascalheira, J., Évora, M., Regala, F., Pereira, T., Manne, T. and Cortés, M. In press: "Nuevas evidencias sobre el Paleolítico Superior inicial del Suroeste Peninsular: el Gravetiense Vicentino de Vale Boi (sur de Portugal)". Proceedings of the meeting Gravetiense Cantábrico: Estado de la Cuestión. Museo de Altamira.

MarReiros, J., CAsCALHeIRA, J. and Bicho, N. 2012: "Flake production in the Early Upper Paleolithic assemblages of Vale Boi (Southern Portugal)". In A. Pastoors and M. Peresani (eds.): Flakes not blades: the role of flake production at the onset of the Upper Palaeolithic in Europe. Wissenschaftliche Schriften des Neanderthal Museums. Mettman: 11-23.

Pereira, T., Cascalheira, J., Marreiros, J., Almeida, F. and Bicho, N. 2012: "Variation in quartzite exploitation during the Upper Palaeolithic of Southwest Iberian Peninsula". Trabajos de Prehistoria 69 (2): 232-256.

Quelhas, A. and Zambujo, G. 1998: "Jazidas paleoliticas no concelho de Lagos (Algarve): abordagem preliminar". Revista Portuguesa de Arqueologia 1 (2): 5-18.

RegalA, F. 2011: Os Adornos do Paleolitico Superior de Vale Boi. Master thesis. Universidade do Algarve, Portugal.

Reimer, P., Baillie, M., Bard, E., Bayliss, A., Beck, J., Blackwell, P., Bronk Ramsey, C., Buck, C., BurR, G., Edwards, R., Friedrich, M., Grootes, P., 
Guilderson, T., Hajdas, I., Heaton, T., Hogg, A., Hughen, K., Kaiser, K., Kromer, B., Mccormac, F., Manning, S., Reimer, R., Richards, D., Southon, J., Talamo, S., Turney, C., Van Der Plicht, J. and Weyhenmeyer, C. 2009: "IntCal09 and Marine09 radiocarbon age calibration curves, 0-50,000 years cal BP". Radiocarbon 51(4): 1111-1150.

SANTOS, E. 2005: "Estudo preliminar das matérias-primas líticas de Vale Boi (Vila do Bispo, Algarve)". In N. Bicho (ed.) O Paleolítico. Actas do IV Congresso de Arqueologia Peninsular. Universidade do Algarve. Faro: 447-455.

SimÓN, M., CORTÉS, M. and BıCHO, N. 2012: "Primeras evidencias de arte mueble paleolítico en el sur de Portugal". Trabajos de Prehistoria 69 (1): 7-20.

SMITH, P. 1966: Le Solutréen en France. Delmas. Bordeaux.

STINER, M. 2003: "Zooarchaeological evidence for resource intensification in Algarve, Southern Portugal". Promontoria 1: 27-61.

Stout, D. 2002: "Skill and cognition in stone tool production". Current Anthropology 43: 693-715.

StRaus, L. 1976: "A new interpretation of the Cantabrian Solutrean". Current Anthropology 17: 342-343.

- 1977: "Pointes solutréennes et l'hypothèse du territorialisme". Bulletin de la Société Préhistorique Française 74: 206-12.

- 1991: "SW Europe at the Last Glacial Maximum". Current Anthropology 32: 189-199.

Straus, L. and Clark, G. 1986: La Riera Cave. Stone Age Hunter-Gatherer Adaptations in Northern Spain. Anthropological Research Papers $n^{\circ}$ 36. Arizona State University. Arizona.

Straus, L., Bicho, N. and Winegardner, A.-C. 2000: "The Upper Paleolithic settlement of lberia: first generation maps". Antiquity 74(3): 553-566.
StRAUS, L. 1990: "The original arms race: Iberian perspectives on the Solutrean phenomenon". In J. K. Kozlowski (dir.) Feuilles de pierre. Les industries à pointes foliacées du Paléolithique supérieur européen. Actes du Colloque de Cracovie 1989. Études et Recherches Archéologiques de l'Université de Liège. Liége: 425-447.

TIFFAGOM, M. 2006: De la pierre à l'Homme. Essai sur une paléoanthropologie solutréenne. ERAUL. Liége.

Verissimo, H. 2004: "Jazidas siliciosas da região de Vila do Bispo (Algarve)". Promontoria 2:35-48.

- 2005: "Aprovisionamento de materiais líticos na Pré-história do Concelho de Vila do Bispo". In N. Bicho (ed.): O Paleolitico. Actas do IV Congresso de Arqueologia Peninsular. Universidade do Algarve. Faro: 509-523.

VIANA, A. 1947: "Paleolítico dos arredores de Beja e do litoral algarvio "zona sotavento»". Brotéria 45 (1): 45-57.

VILLAVERDE, V. 1994: Arte paleolítico de la cova del Parpalló. Estudio de la colección de plaquetas y cantos grabados y pintados. Diputación de Valencia. Valencia.

Zambujo, G. and PIRES, A. 1998: "O sítio arqueológico da Vala, Silves: Paleolítico Superior e Neolítico antigo". Revista Portuguesa de Arqueologia 2 (1): 5-24.

ZILHÃO, J. 2013: Seeing the leaves and not missing the forest: a portuguese perspective of the Solutrean. In A. Pastoors and B. Auffermann (eds.) Pleistocene foragers on the Iberian Peninsula: their culture and environment. Neanderthal Museum. Mettman: 201-216.

- 1997: O Paleolítico Superior da Estremadura portuguesa. Colibri. Lisboa. 
